\title{
The Role of Technology Acceptance Model in Explaining University Academics' Acceptance and Behavioural Intention to Use Technology in Education
}

\section{Tanimu Adamu Ibrahim}

Department Of Education, Faculty Of Education, Bayero University, Kano-Nigeria

\section{Abstract}

As the use of modern technology in education continues to grow at all levels of education, and academics are believe to be among the major actors in educational transformation, there is an increasing need to better understand the acceptance and behavioural intention of University academics to use technology in education because few studies were conducted to that effect. Hence, the purpose of this research was

Corresponding Author: Tanimu Adamu Ibrahim taibrahim.edu@buk.edu.ng

Received: 23 April 2018 Accepted: 8 May 2018 Published: 4 June 2018

Publishing services provided by Knowledge E

(c) Tanimu Adamu Ibrahim. This article is distributed under the terms of the Attribution License, which permits unrestricted use and redistribution provided that the original author and source are credited.

Selection and Peer-review under the responsibility of the IRCHE 2017 Conference Committee. to find the level of technology acceptance among university academics using TAM as theoretical model. A survey was used using a sample of 355 academics from Nigerian universities. Regression analysis and Structural Equation Modelling (SEM) were used for the data analyses and model fit using SPSS and AMOS softwares. The result proved TAM to be a good theoretical tool to understand users' acceptance of technology. The findings revealed that the variances in Self Efficacy (SE), Social Influence (SI), System Accessibility (SA), Perceived Usefulness (PU) and Perceived Ease of Use (PEOU) really contribute to change in Behavioural Intention (BI) to use technology. However, the study also revealed that there are significant relationships between $\mathrm{BI}$ and $\mathrm{SE}$, $\mathrm{SA}$, and $\mathrm{PU}$, but insignificant relationship was found between $\mathrm{BI}$ and the other two constructs i.e PEOU and SI. Since technology is not easy to use, and there is less social influence to help them use the system adequately, therefore, perhaps there is need for management to organize more trainings, seminars and workshops with regards to the use of the technology for the academics.

Keywords: Analysis of Moment Structure (AMOS), Behavioural Intention, Structural Equation Modelling (SEM), Technology Acceptance Model (TAM).Introduction

Improved, modern education in developing countries provides the promise of meaningful employment for graduates, movement towards a knowledge-based economy, and rapid national economic growth. Indeed, Africa has recently been leapfrogging 
communications technologies at speedy level and pace unlike before. This phenomenon brings hope to the possibility of schools being able to use new technologies to leapfrog over many of their problems for positive transformation. Technology may assist with this transformation. The concept of technology integration into an educational system begins with the teacher and the ways in which teachers teach. This starts with pedagogy, the art and science of teaching. The academic approach to this subject discusses the theoretical perspectives of behaviorism versus constructivism. A simplistic description of the view is that of "chalk and talk" and the teacher as the ultimate authority and purveyor of knowledge - the "sage on the stage". The challenge for many if not most teachers, particularly in developing countries, is changing their practice of teaching in ways that accommodate the use of technology. Blending how they have traditionally practiced teaching with the use of technology beings to create technology solutions. In technology, technology is simply a tool that educators may use in a number of ways within the new environment that can impact student learning and outcomes.

\section{Problem statement}

The successful implementation of technology tools depends on the perception of the users and also their knowledge and skills in using computers (Chesney, (2006). Such major factors have been shown to affect users' initial acceptance of computer technology. Due to its acceptable explanatory power and popularity, many studies have used the Technology Acceptance Model (TAM) in the technology acceptance and adoption of various Information System implementation area and especially in technology context (Park, 2009). However, it is unclear whether the model holds for technology perception and acceptance in developing countries. TAM's reliability and validity and thus its generalizability are still questionable as it was criticised for its cultural bias especially when tested in non-western countries (Park, 2009). Additionally, TAM suffers from other limitations such as inconsistencies in previous studies and is still questionable in explaining the social influence on the acceptance of technology (Straub, Keil and Brenner, 1997; Gefen and Straub, 1997 \& Venkatesh and Davis, 2000).

Thus, the purpose of this current study is to address the above limitations. Specifically, this research focuses on the factors that affect academics' acceptance and usage of technology in teaching learning process using TAM and additional variables. 


\section{Objectives of the Study}

This study proposed an integrated theoretical framework (model) of university academics' Behavioural Intention to use technology based on the Technology Acceptance Model (TAM). The following are specific objectives of this study:

- To develop a general linear structural model of technology acceptance among Nigerian university academics.

- To examine the relationships of academics behavioural intention to use technology with their self-efficacy, Social Influence, system accessibility, perceived usefulness, and perceived ease of use.

\subsection{Research hypotheses}

In accordance with the previously stated objectives and consistent with related literature, this study tested the following null hypotheses:

- $\mathrm{Ho}_{1}$ : There is no significant relationship between Technology Self-efficacy and Behavioural Intention to use technology by university academics.

- $\mathrm{Ho}_{2}$ : There is no significant relationship between Social Influences and Behavioural Intention to use technology by university academics.

- $\mathrm{Ho}_{3}$ : There is no significant relationship between System Accessibility and Behavioural Intention to use technology by university academics.

- $\mathrm{Ho}_{4}$ : There is no significant relationship between Perceive Usefulness and Behavioural Intention to use technology by university academics.

- $\mathrm{Ho}_{5}$ : There is no significant relationship between Perceive Ease of Use and Behavioural Intention to use technology by university academics.

\subsection{Literature review and theoretical framework}

Electronic learning, or technology, is education based on modern methods of communication including the computer and its networks, various audio-visual materials, search engines, electronic libraries, and websites, whether accomplished in the classroom or at a distance. The definition of technology centers on its being a learning method and a technique for the presentation of academic curricula via the Internet or any other electronic media inclusive of multimedia, compact discs, satellites, or other new education technologies (Park, 2009). 
One of the well-known models related to technology acceptance and use is the technology acceptance model (TAM), originally proposed by Davis in 1986. TAM has proven to be a theoretical model in helping to explain and predict user behavior of information technology (Legris, Ingham, \& Collerette, 2003). TAM is considered an influential extension of theory of reasoned action (TRA), according to Ajzen and Fishbein (1980). Davis (1989) and Davis, Bagozzi, and Warshaw (1989) proposed TAM to explain why a user accepts or rejects information technology by adapting TRA. TAM evolve over time and provides a basis with which one traces how external variables influence belief, attitude, and intention to use. Two cognitive beliefs are posited by TAM: perceived usefulness and perceived ease of use. According to TAM, one's actual use of a technology system is influenced directly or indirectly by the user's behavioral intentions, attitude, perceived usefulness of the system, and perceived ease of the system. TAM also proposes that external factors affect intention and actual use through mediated effects on perceived usefulness and perceived ease of use. Figure 1 depicts the original TAM (Davis, 1989).

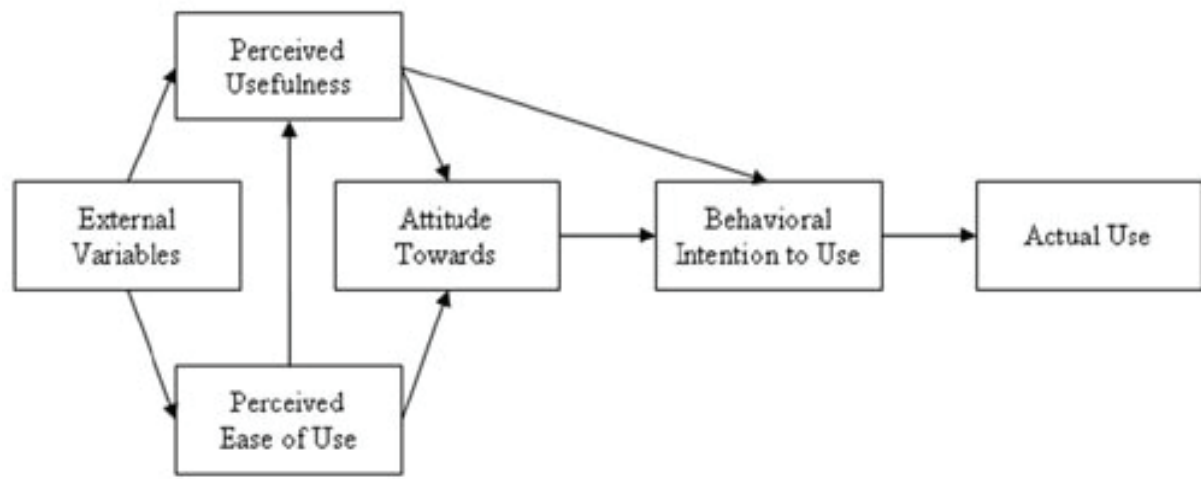

Figure 1: Original technology acceptance model (TAM).

TAM appears to be able to account for 40 percent to 50 percent of user acceptance. TAM2 extended the original model to explain perceived usefulness and usage intentions including social influence (Social Influence, voluntariness, and image), cognitive instrumental processes (job relevance, output quality, and result demonstrability) and experience. The new model was tested in both voluntary and mandatory settings. The results strongly supported TAM2 and explained 60 percent of user adoption using this updated version of TAM (Venkatesh \& Davis, 2000). 


\section{Researcher's Suggested Model}

For the purpose of this research, the researcher adapt the TAM (Davis, 1989) with some additional variables. The additon seems necessary as the researcher's personal experiences coined with some suggestions from various literatures (example, Park 2009) which support their relavances in predicting user behaviour in relation to technology acceptance and usage. The variables were added in order to have a comprehensive understanding of the university lecturers' acceptance and behavioural intention to use technology. The hypothesized research model is shown in Figure 2.

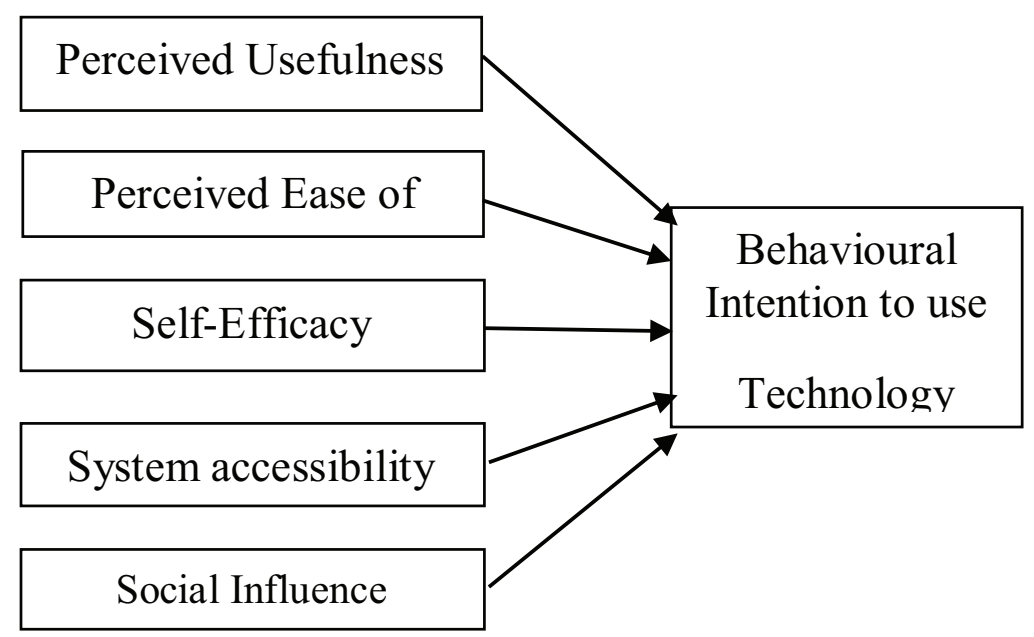

Figure 2: Researcher specified Model.

\section{Methodology}

A descriptive survey design was employed for this research. The population consisted of all academics of Northern Nigerian universities. The academics of all ranks (Graduate assistant, Assistant lecturer, lecturer I, Lecturer II, Associate Professor and Professor) and disciplines (Agriculture, Education, Humanities, Social sciences, Sciences, Medical Sciences and Technology) were considered for the study. Three hundred and fifty five (355) questionnaires were distributed for the study.

TABLE 1: Sampled Universities.

\begin{tabular}{c|c|c|}
\hline SN & Status & Sampled Universities \\
\hline 1 & State & Sule Lamido University, Kafin Hausa \\
\hline 2 & State & Umar Musa Yar'adua University, Katsina \\
\hline 3 & Federal & Bayero University, Kano \\
\hline 4 & Federal & Federal University Dutsin-Ma \\
\hline
\end{tabular}


Furthermore, the researcher used cluster sampling technique to select the number of participants from each category of academic staff from each university. The categories that were considered as clusters were; staff's academic ranks (Graduate assistant, Assistant lecturer, lecturer I, Lecturer II, Associate Professor and Professor) and their disciplines (Agriculture, Education, Humanities, Social sciences, Sciences, Medical Sciences and Technology). The summary of sampled academics based on their ranks (Graduate assistant, Assistant lecturer, lecturer I, Lecturer II, Associate Professor and Professor) is presented in table 2.

TABLE 2: Sample of the respondents by Academic ranks in percentages (\%).

$\mathrm{S} / \mathrm{N}$
1
2
3

Academic ranks
Graduate assistant \& Assistant lecturer
Lecturer II \& Lecturer I
Senior lecturer, Reader \& Professor
TOTAL

\begin{tabular}{|c|c|}
\hline No. & $\%$ \\
\hline 172 & $48 \%$ \\
\hline 130 & $37 \%$ \\
\hline 53 & $15 \%$ \\
\hline 355 & $100 \%$ \\
\hline
\end{tabular}

The members of each cluster of academic disciplines (Agriculture, Education, Humanities, Social Sciences, Sciences, Medical Sciences and Technology) were selected proportionate to their number in each university. The required sample size of each university was shared among the clusters, proportionate to the available elements in the clusters.

TABLE 3: Sample of the respondents by Academic disciplines in percentages (\%).

Finally, the researcher used simple random sampling technique in selecting the subjects from each university.

The response rate of the participants was determine to ensure that the adequate number of questionnaires were retrieved for analysis. To calculate the response rate, the researcher divides the number of people who submitted completed questionnaires by the number of people contacted. According to the American Association for Public Opinion Research, 2000, the response rate should be at least $70 \%$ to be adequate for data analysis. In this study, the number of people contacted was 355 and the number of completed questionnaires were 278 , so the response rate was approximately $78 \%$, which appeared to be adequate for the analysis. 


\section{Instrumentation}

The items from the different constructs were all adapted from various technology acceptance studies based on the characteristics intended for this study on Likert scale. Validity and reliability of the items were established using Amos software.

\section{Construct Validity}

An instrument is said to be valid when the Cronbach Alpha is more than 0.8 and not less than 0.6 (Chua, 2006). The Cronbach Alpha for all the constructs in this study are more than 0.7 (Table 4 ).

TABle 4: Alpha Cronbach score.

Constructs
Perceive usefulness (PU)
Perceive Ease of Use (PEOU)
Self-Efficacy (ESE)
System Accessibility (SA)
Social Influences (SN)
Behavioural Intention (BI)

\begin{tabular}{c|c|}
\hline Cronbach $\alpha$ \\
0.841 \\
0.712 \\
0.961 \\
0.950 \\
0.893 \\
0.812 \\
\hline
\end{tabular}

\section{Reliability of the Instrument}

Reliability is the degree to which measures are free from error and therefore yield consistent results (i.e. the consistency of a measurement procedure). For the purpose of this study Cronbach's alpha was used to determine the reliability of the instrument using SPSS software. Cronbach's alpha is a reliability coefficient that measures interitem reliability or the degree of internal consistency/homogeneity between variables measuring one construct/concept i.e. the degree to which different items measuring the same variable attain consistent results. This coefficient varies from o to 1 . In the social sciences, acceptable reliability estimates range from.70 to.80 (Nunnally \& Bernstein, 1994). The obtained Cronbach's alpha in this study (Table 5) is.835 which indicated that the instrument is reliable for the study. 


\section{Results}

\subsection{Testing suggested model}

\subsubsection{Anova analysis}

The F-ratio given under column $\mathrm{F}$ is $13.403, p$-value,.000 is given under Sig. column. Since $p$-value is less than the 0.05 , it inferred that the calculated regression coefficient is significant and the variance in the independent variables contribute to the change in dependent variable.

TABLE 5: ANOVA TABLE.

\begin{tabular}{|c|c|c|c|c|c|c|}
\hline \multicolumn{2}{|r|}{ Model } & Sum of Squares & Df & Mean Square & $\mathbf{F}$ & Sig. \\
\hline \multirow[t]{3}{*}{1} & Regression & 14.153 & 5 & 2.831 & 13.403 & $.000^{b}$ \\
\hline & Residual & 57.445 & 272 & .211 & & \\
\hline & Total & 71.598 & 277 & & & \\
\hline \multicolumn{7}{|c|}{ a. Dependent Variable: BI } \\
\hline \multicolumn{7}{|c|}{ b. Predictors: (Constant), SA, SE, SI, PU, PEOU } \\
\hline
\end{tabular}

\subsubsection{Regression analysis}

Regression is a statistical technique to determine the linear relationship between two or more variables. Regression is primarily used for prediction and causal inference.

TABLE 6: Regression analysis (dependent variable = BI).

\begin{tabular}{|l|c|c|c|c|c|}
\hline Ho & Relationship & $(\beta)$ & t value & Sig. & Result \\
\hline $\mathrm{Ho}_{1}$ & $\mathrm{SE}-\mathrm{BI}$ & .168 & 2.420 & .016 & Accepted \\
\hline $\mathrm{Ho}_{2}$ & $\mathrm{SI}-\mathrm{BI}$ &.-138 & -2.413 & .016 & Rejected \\
\hline $\mathrm{Ho}_{3}$ & $\mathrm{SA}-\mathrm{BI}$ & .149 & 2.687 & .008 & Accepted \\
\hline $\mathrm{Ho}_{4}$ & $\mathrm{PU}-\mathrm{BI}$ & .231 & 4.050 & .000 & Accepted \\
\hline $\mathrm{HO}_{5}$ & $\mathrm{PEOU}-\mathrm{BI}$ &.-159 & -2.220 & .027 & Rejected \\
\hline
\end{tabular}

The result in Table 8 showed that Technology Self-Efficacy $(\beta=0.168, p<0.05)$, System Accessibility $(\beta=0.149, P<0.05)$, Perceive Usefulness $(\beta=0.231, p<0.05)$ have positive effect on Behavioural Intention (BI). However, Perceive Usefulness is found to show the biggest influence on Behavioural Intention ( $\beta=0.231$ ). Therefore, Ho1, $\mathrm{H}_{3}$, and $\mathrm{Ho}_{4}$ for this study are accepted. Nevertheless, Perceive Ease of Use ( $\beta=-$ 0.159 ) and Social Influence $(\beta=-0.138, p>0.05)$ have no positive effect on Behavioural Intention (BI), as such, $\mathrm{Ho2}$ and Ho5 are rejected. 


\section{Discussion and Conclusion}

This study focused on the factors that affect the acceptance Technology systems among academics of Northern Nigerian Universities. A conceptual model that extends the TAM to include Technology self-efficacy, social influence, and system accessibility constructs as main determinants was proposed. The results show that all the direct relationship between PEOU, PU, SA, SI and ESE with BI (with $44.5 \%$ of its variance explained) were supported. These results are very close to traditional TAM as proposed by Davis (1989).

Different from most of the studies that consider western countries, this study supports TAM's reliability and validity in an educational context in the developing world and more specifically in Northern Nigerian Universities. The results revealed that Technology is well accepted among Universities academics in Northern Nigeria despite all the possible challenges. Although TAM and other user acceptance models have been validated empirically, research continues to add social factors to overcome the limited explanatory power of such models. This study moves in that direction. By including technology self-efficacy, social influence and system accessibility as main constructs.

\section{Conclusion and Recommendations}

The analysis on the five constructs of the suggested model showed that three of the hypotheses were accepted while the other two were rejected. Perceive Usefulness, Technology self-efficacy, and system accessibility have significant relationship with Behavioural Intention whereas Perceive ease of use and social Influence have no significant relationship with Behavioural Intention.

The study concludes that the acceptance factors of the technology among academics are that the teachers believe that technology system can help them increase their teaching performance; there is system accessibility and also they have selfefficacy in the use of technology. Nevertheless, this study also found that teachers claimed that the technology is not easily use and operated. Therefore, perhaps the management can organize more training with regards to the use of the technology for the academics.

The researcher believes that the scope of the population has to be widened to obtain a more solid and rich data collection. Besides, the constructs that were studied were only five and they are based on the constructs from the TAM I Model which was introduced by Davis (1989) the researcher suggests that the UTAUT I Model by 
Venkatesh (2003) should be used to test the technology acceptance among Nigerian academics. This is due to the fact that the UTAUT model has added new constructs.

\section{References}

[1] Ajzen, I., \& Fishbein, M. (1980). Understanding attitudes and predicting social behavior. Englewood Cliffs, NJ: Prentice-Hall.

[2] Ajzen, I. (1991). The theory of planned behavior. Organizational Behavior and Human Decision Processes, 50, 179-211.

[3] Cronbach, L.J., \& Meehl, P.E. (1955) Construct Validity in Psychological Tests, Psychological Bulletin, 52: 281- 302.

[4] Davis, F. D. (1986). A technology acceptance model for empirically testing new enduser information systems: Theory and results. Doctoral dissertation. Cambridge, MA: MIT Sloan School of Management.

[5] Davis, F. D. (1989). Perceived usefulness, perceived ease of use, and user acceptance of information technology. MIS Quarterly, 13(3), 319-339.

[6] Davis, F. D., Bagozzi, R. P., \& Warshaw, P. R. (1989). User acceptance of computer technology: A comparison of two theoretical models. Management Science, 35(8), 982-1003.

[7] Grandon, E., Alshare, 0., \& Kwan, O. (2005). Factors influencing student intention to adopt online classes: A cross-cultural study. Journal of Computing Sciences in Colleges, 20(4), 46-56.

[8] Gefen D., and Straub, D. W. (1997). "Gender differences in the perception and use of e-mail: An extension to the technology acceptance model," MIS quarterly, 1997, pp. 389-400.

[9] Legris, P., Ingham, J., \& Collerette, P. (2003). Why do people use information technology? A critical review of the technology acceptance model. Information \& Management, 40, 191-204.

[10] Malhotra, Y., \& Galletta, D. F. (1999). Extending the technology acceptance model to account for social influence: Theoretical bases and empirical validation. Proceedings of the 32nd Hawaii International Conference on System Sciences, 1999.

[11] Nunnally, J.C., and Bernstein, I.H. (1994) Psychometric Theory, (3rd edn), McgrawHill: New York

[12] Park S. Y. (2009). "An analysis of the technology acceptance model in understanding university students' behavioral intention to use technology," Educational Technology \& Society, 2009, vol. 12, no. 3, pp. 150-162. 
[13] Straub D., Keil M., and Brenner W. (1997). "Testing the technology acceptance model across cultures: A three country study," Information \& Management, 1997, vol. 33, no. 1, pp. 1-11.

[14] Venkatesh, V., \& Davis, F. D. (1996). A model of the antecedents of perceived ease of use: Development and test. Decision Sciences, 27, 451-481.

[15] Venkatesh, V., \& Davis, F. D. (2000). A theoretical extension of the technology acceptance model: Four longitudinal filed studies. Management Science, 46, 186204.

[16] Venkatesh, V., Morris, M. G., Davis, G. B., \& Davis, F. D. (2003). User acceptance of information technology: Toward a unified view. MIS Quarterly, 27(3), 425-478.

[17] Edition, Publisher, ISBN No. (if any), pp. (Printed Pages i.e. pp. 45-51)

[18] Author Name (s). (Year). Title of the Technical Report, Publisher, ISBN No. (if any), pp. (Printed Pages i.e. pp. 45-51)

[19] For online article: Author Name (if any), Title of the Article, URL: (i.e. http:// psychology.about.com/od/apastyle/ig/APA-Format-Examples/references.htm), date retrieved:

[20] Author Name (s), Title of the Paper/Article, Proceedings of <Name of the conferences, Date \& Year, Place \& Country, Volume No., ISBN No. (if any), pp. (Printed Pages i.e. pp. 45-51) 